\title{
ANÁLISE DAS CONDICCÕES DE SUSTENTABILIDADE AMBIENTAL DA PRODUÇÃO AGROPECUÁRIA NOS ASSENTAMENTOS RURAIS DE CONCEIÇÃO DO ARAGUAIA - PA
}

\author{
Rafael Miranda Arraz ${ }^{1}$ \\ Elineide Eugênio Marques ${ }^{2}$ \\ Luis Fernando da Silva Laroque ${ }^{3}$ \\ Julia Elisabete Barden ${ }^{4}$
}

\begin{abstract}
RESUMO
Os modos de vida e produtivos dos pequenos produtores com relação ao desenvolvimento rural no campo, como é o caso das Unidades Familiares de Produção (UFP) no município de Conceição do Araguaia/Pará, podem tornar-se reflexo direto das condições de sustentabilidade evidenciados por suas formas organizativas, por seus meios e técnicas de produção. O presente artigo analisa as condições de sustentabilidade nos assentamentos rurais do município de Conceição do Araguaia/Pará manifestadas nas produções agropecuárias focado na dimensão ambiental das Unidades Familiares de Produção UFP em dois Assentamentos da reforma agrária no mesmo município, no sudeste paraense, às margens do rio Araguaia. O método utilizado foi o exploratório, com abordagem qualitativa e de coleta de dados por meio de entrevistas, diários de campo e registros fotográficos. Foram investigadas as práticas conservacionistas, a paisagem da propriedade e a diversidade da produção dos assentamentos rurais, identificando os manejos implementados, os impactos ambientais da produção com relação à sustentabilidade. Os resultados dos indicadores e atributos de sustentabilidade evidenciaram a fragilidade ambiental nos assentamentos, o que poderá comprometer a fixação destas famílias nas UFP e a longevidade da atividade agropecuária promovida pelos produtores no aproveitamento dos recursos naturais com sustentabilidade.
\end{abstract}

Palavras-chave: Unidades Familiares de Produção. Produções sustentáveis. Sudeste Paraense. Indicadores de sustentabilidade.

\footnotetext{
${ }^{1}$ Mestre em Ambiente e Desenvolvimento pela Universidade do Vale do Taquari (UNIVATES) e Doutorando em Ciências do ambiente na Universidade Federal do Tocantins (UFT); Professor do Instituto Federal da Pará (IFPA), em Conceição do Araguaia/PA, (Brasil). E-mail: rafael.arraz@mail.ifpa.edu.br Orcid: http://orcid.org/0000-0002-7875-2689

${ }^{2}$ Doutora em Ecologia de Ambientes Aquáticos Continentais pela Universidade Estadual de Maringa (UEM); Professora Associada da Universidade Federal do Tocantins (UFT), Palmas e Porto Nacional/TO (Brasil), E-mail: emarques@mail.uft.edu.br Orcid: http://orcid.org/0000-0003-0223-6853.

${ }^{3}$ Doutor em História pela Universidade do Vale do Rio dos Sinos (UVRS); Professor da Universidade do Vale do Taquari (UNIVATES), em Lajeado/RS, (Brasil). E-mail: Iflaroque@univates.br Orcid: https://orcid.org/0000-0003-1861-4679

${ }^{4}$ Doutora em Economia com ênfase em Economia do Desenvolvimento pela Universidade Federal do Rio Grande do Sul (UFRGS); Professora da Universidade do Vale do Taquari (UNIVATES), em Lajeado/RS, (Brasil). E-mail: jbarden@univates.br Orcid: http://orcid.org/0000-0002-9818-1844
} 

AGRICULTURAL PRODUCTION IN RURAL SETTLEMENTS OF CONCEIÇÃO DO ARAGUAIA - PA

\begin{abstract}
In the lively and productive ways of small producers regarding rural development in the countryside, as is the case of the Family Production Units (UFP) in the municipality of Conceição do Araguaia / Pará, can become direct reflections sustainability conditions evidenced by their organizational forms, by their means and production techniques. This article analyzes the conditions of sustainability in rural settlements in the municipality of Conceição do Araguaia / Pará manifested in agricultural production focused on the environmental dimension of UFP Family Production Units in two Agrarian Reform Settlements in the same municipality, in southeastern Pará, on the banks of the Araguaia River. The method used was exploratory, with qualitative approach and data collection through interviews, field diaries and photographic records. Conservationist practices were investigated, the landscape of the property and the diversity of production in rural settlements, identifying the implemented managements, the environmental impacts of production in relation to sustainability. The results of the sustainability indicators and attributes showed environmental fragility in the settlements, what could compromise the fixation of these families in UFP and the longevity of the agricultural activity promoted by the producers in the use of natural resources with sustainability
\end{abstract}

Keywords: Family Production Units. Sustainable production. Southeast Paraense. Sustainability indicators.

\title{
1 INTRODUÇÃO
}

O modo de vida da sociedade contemporânea em busca do consumo promove a exploração agressiva dos recursos naturais, a ponto de comprometer a continuidade do seu uso em vários casos. Nas últimas décadas este assunto esteve nas pautas de discussões internacionais, principalmente quanto às suas mitigações.

Na Amazônia, especialmente no Sudeste Paraense, a prática da agricultura familiar tem representado bem mais que uma fonte de emprego e renda para centenas de famílias. A agricultura familiar tem significado para muitos a ampliação das possibilidades de uma reprodução social camponesa ${ }^{5}$ e a oportunidade de estruturar

\footnotetext{
${ }^{5}$ Muitas terminologias foram utilizadas historicamente para o mesmo sujeito: camponês, pequeno produtor, lavrador, agricultor familiar. São devidas as novas percepções sobre a mesma categoria social, carregada de profundo significado político-ideológico. Os camponeses eram identificados nos diferentes tipos de minifúndios, expressava a oposição aos latifúndios e que podia ser encontrada na estrutura agrária do Brasil, procurava-se o sujeito da mudança social para alcançar uma estrutura mais justa e digna para esses atores sociais (WANDERLEY, 2014).
} 
a identidade social desse grupo a partir da recuperação dos vínculos com a terra e o desenvolvimento de sistemas familiares de produção agropecuários próprios.

No Brasil, conforme Macedo (2006), historicamente tem ocorrido um processo de concentração de terras nas mãos de poucos, em detrimento de outras formas de uso como aquela da agricultura camponesa, dos grupos indígenas e quilombolas e outras comunidades tradicionais, que valorizam formas de produzir menos impactante.

Assim, o objetivo deste artigo é analisar qualitativamente as condições de sustentabilidade nos assentamentos rurais Canarana e Padre Josimo Tavares localizados no município de Conceição do Araguaia/Pará. A questão norteadora da pesquisa foi o de conhecer como são as condições de sustentabilidade ambiental nas produções agropecuárias manifestadas nos assentamentos rurais do município de Conceição do Araguaia. A pesquisa encontra-se na linha de estudo de problemas socioambientais. Para alcançar a resposta ao problema da pesquisa apresentada, bem como contribuir com experiências de produtores familiares da região estudada, definiu-se como público-alvo nos Assentamentos Rurais da Canarana e Padre Josimo Tavares aqueles que tivessem alguma atividade produtiva em suas propriedades e que atuassem em suas respectivas produções agropecuárias, além é claro de suas disponibilidades em receber o pesquisador.

Para atender a perspectiva deste artigo, que seria discutir de forma qualitativa as condições de sustentabilidade em assentamentos rurais nas áreas já mencionadas, foi realizada a construção de indicadores de sustentabilidade a partir da relação de atributos de sustentabilidade com a dimensão ambiental, servindo de parâmetros nos levantamentos de dados a serem discutidos, nos sistemas produtivos agropecuários que tendem a contribuir para facilitar a gestão das propriedades rurais pelos produtores, bem como proporcionar esclarecimentos acerca de aspectos legais e garantia da qualidade dos produtos, que foram baseados nos estudos dos autores Schult, Barden e Laroque (2010).

\section{FUNDAMENTAÇÃO TEÓRICA}

Para fundamentação da temática são apresentados alguns conceitos no âmbito do desenvolvimento agropecuário na Amazônia, sustentabilidade da agricultura 
familiar em assentamentos rurais no Sudeste do Pará, os possíveis entraves e as políticas públicas necessárias para a agropecuária ser de fato sustentável.

\subsection{Desenvolvimento agropecuário na Amazônia}

As atividades produtivas no âmbito do desenvolvimento agropecuário na Amazônia estão associadas ao aumento do desmatamento. As florestas são derrubadas para a instalação de áreas agropastoris, seja em pequenas áreas, como comumente encontrada nas unidades familiares de produção em assentamentos rurais, ou em grandes áreas, como na pecuária extensiva, que é a atividade dominante na Amazônia brasileira e em específico no sudeste paraense (FEARNSIDE, 2017). A abertura de novas áreas agrícolas e pecuárias na Amazônia tem se refletido na imposição de Planos, Programas e Projetos de desenvolvimento elaborados por sujeitos externos e sem discussão ou sintonia com os moradores locais. Esse modelo de governança desfavoreceu a organização e o planejamento na justiça agrária, pois consequentemente implicou em efeitos jamais esquecidos, particularmente na Amazônia: os conflitos, as chacinas, os assassinatos, as torturas, perseguições principalmente onde os mais atingidos foram setores marginalizados econômica e politicamente, como os povos indígenas, camponeses, camponesas, seus filhos e filhas (BRASIL, 2006).

As frentes migratórias deram-se principalmente na década de 1970, constituídas fundamentalmente por contingentes de origem rural vindas de diversas regiões do país, fazendo os percursos clássicos de avanço - contínuo ou por etapas desde áreas da Região Nordeste para a Amazônia Oriental, ou mesmo o aprofundamento de frentes anteriores, provenientes do Sul e do interior de São Paulo e Minas, que avançaram em direção ao Noroeste brasileiro, passando por Mato Grosso. Nas décadas de 1960 e 1970 foram centenas de milhares de migrantes que percorreram esses caminhos, em busca de terras disponibilizadas por projetos de assentamentos e pequenas e médias fazendas destinadas à criação de gado, que ainda é a atividade mais incisiva no processo de colonização da Amazônia nos governos militares. Este modelo segue os processos produtivos desenvolvimentistas de outras regiões brasileiras (OLIVEIRA, 1983). As fazendas, vastos domínios de muitos milhões de hectares, segundo Tourrand et al. (1995), ocupam entre 70 e 90\% 
do espaço colonizado conforme as regiões utilizadas pelas atividades agropecuárias na Amazônia, indicando a concentração de terras e uma injustiça agrária.

Com as notórias concentrações de terras do modelo de produção agropecuário para a Amazônia percebe-se mais um obstáculo ao desenvolvimento regional, com a constatação da baixa fertilidade dos solos amazônicos (SERRÃO, 1986). As pastagens implantadas começaram a se degradar a partir do quinto ano de utilização, mas mesmo diante destas condições a pecuária continuou a se expandir na região com desmatamentos e estabelecimento de grandes áreas de exploração (VEIGA; FALESI, 1986).

Para Santos (2010), a pecuária, mesmo com as dificuldades enfrentadas nos manejos de pastos que a inviabilizou, exigiu ainda mais a contratação de mão de obra de trabalhadores rurais, que muitas vezes sonhavam e queriam lutar por um pedaço de terra. Desta forma, encontrava-se aí uma divergência de interesses e dando início a uma dinâmica de luta e reinvindicação para a criação de assentamentos na região que está relacionada com os conflitos territoriais e as expropriações de terras para fins de estruturação da reforma agrária.

\begin{abstract}
A implantação de grandes projetos criou um modelo de relação social no campo baseado na contratação de camponeses para trabalhos assalariados em contraposição ao modelo vigente baseado na agricultura familiar. $O$ resultado mais visível desse processo foi a intensa derrubada da floresta e a concentração fundiária e de renda que vieram junto com muita violência contra os trabalhadores rurais, além de conflitos resultantes da expropriação de centenas de povoados (SANTOS, 2010, p. 27).
\end{abstract}

A criação de assentamentos rurais não se restringe à redução da pobreza rural. As experiências nestes meios rurais em construção representam inovações na gestão territorial, permitindo aos assentados e produtores a reconstituição de modos de vida ligados ao meio rural e inseridos no contexto regional que possam promover um elo com as dinâmicas das relações do trabalho e do ambiente (FERRANTE et al., 2006). Com a implementação dessa nova realidade no meio rural surgiram os primeiros entraves sociais e econômicos relacionados aos detentores de terras cedidas pelo Instituto Nacional de Colonização e Reforma Agrária (INCRA). Ou seja, os interesses em possuir terras e desenvolver atividades agropecuárias aumentaram significativamente.

No processo que envolve a criação de Projetos de Assentamento do Sudeste Paraense, tendo em vista a rápida e ininterrupta ocupação de novas áreas de terra, a 


\section{¿Unisul}

ação do INCRA tem sido muito mais de regularizar ocupações consumadas, do que efetivamente propor ações planejadas e organizadas de reforma agrária e garantir justiça agrária necessária na região supracitada. O fluxo contínuo de migrantes para a região contribuiu para as dificuldades de uma ação planejada de ocupação, orientada por critérios ambientais, de zoneamentos, ou em bases tecnológicas apropriadas (HOMMA et al., 2002). O tratamento de problemas e questões voltadas ao desenvolvimento local perpassa por uma análise da territorialidade, da transposição do espaço, da delimitação do rural e do vínculo inevitável agrícola aos de múltiplos setores, produtos e serviços que ligam à produção, trabalho e capital, a sustentabilidade e aos fatores do desenvolvimento no campo.

\subsection{Sustentabilidade da Agricultura Familiar em Assentamentos Rurais no Sudeste Paraense}

A Região Amazônica, em especial o Estado do Pará, destaca-se por sua localização estratégica quando se considera o avanço do desmatamento. É uma das regiões mais desmatadas no Brasil, devido às grandes alterações nas paisagens naturais decorrentes da expansão agrícola com o advento da soja nos últimos anos e ainda com a pecuária (BRASIL et al., 2014). Contribui também nesses impactos ambientais a distribuição de terras pela Reforma Agrária, que inevitavelmente gera desmatamento. Os assentamentos nessa região somam cerca de 1.055 unidades familiares de produção (UFP) e 221.804 famílias instaladas até o ano de 2013, a maior área de projetos de assentamento entre os Estados Amazônicos.

Os agricultores familiares representam $85,2 \%$ do total de estabelecimentos, ocupam 30,5\% da área total disposta no Brasil para atividades agricultáveis e são responsáveis por 37,9\% do Valor Bruto da Produção Agropecuária Nacional, recebendo apenas 25,3\% do financiamento destinado à agricultura (INCRA, 2015). Com isso, é perceptivel a contradição da valorização da agricultura familiar por parte dos governantes brasileiros, haja vista que poderímos potencializar o fortalecimento da produção com sustentabilidade com a distribuição de terra e crédito para a agricultura familiar.

Infelizmente, o modelo implantado de distribuição de áreas e de créditos para as produções agropecuárias não é justo e nem coerente com o discurso governamental, por isso esse fato reforça a injustiça social e econômica. 
A maioria dos agricultores familiares enfrenta fortes restrições de recursos em geral e de terra em particular. Assim, adota uma estratégia de exploração intensiva dos recursos para a redução de riscos e garantia de segurança alimentar nas suas atividades produtivas, ao mesmo tempo em que busca a diversificação da produção de produtos desenvolvidos pelas famílias nas UFPs, com objetivo de maior dinamização na oferta de produtos em períodos diferentes do ano, ao mesmo que garante a subsistência e melhor qualidade de vida da família. A consequência disso é a adoção de sistemas de produção que combinam um conjunto variado de produtos, tanto para o consumo da família, como para o autoabastecimento de insumos e matérias-primas de utilização do estabelecimento e para comercialização (BUAINAIN; GUANZIROLI, 2004).

Os programas de apoio à Agricultura Familiar, como o Programa Nacional de Fortalecimento da Agricultura Familiar (PRONAF) e o Fundo Constitucional de Financiamento do Norte (FNO) facilitados, além do Programa Bolsa Família (mais direcionado às cidades), como mecanismos de inclusão social, podem auxiliar na viabilidade da manutenção das famílias nas UFP em Assentamentos, mas também criar uma falsa sustentabilidade. As políticas públicas governamentais têm servido como mecanismo de drenagem de recursos públicos e propiciando alto grau de inadimplência dos programas de crédito por não oferecerem apoio em suas execuções, como um suporte de assistência técnica efetiva na administração das ações produtivas. O que se percebe na maioria dos casos é a distribuição de recursos aos agricultores sem uma devida fiscalização de seu uso (SILVA; HOMMA, 2007).

Silva e Homma (2007) comentam que no Sudeste Paraense a relativa facilidade encontrada pelas famílias em obter novas áreas de terra, em locais mais remotos, sem infraestrutura física e cada vez mais distantes dos mercados que possam absorver sua produção agrícola, bem como a disponibilidade de áreas que ainda mantêm grande parte da cobertura vegetal constituída de floresta primária, não só tem agravado os problemas socioambientais verificados como tem dificultado a consolidação da agricultura familiar nos assentamentos da região.

Com a possibilidade da exclusão do pequeno agricultor familiar das potencialidades de mercado, muitas vezes ele acaba submetendo-se a atravessadores e com isso reduzindo sua remuneração e viabilidade de seus empreendimentos para sua fixação nos assentamentos rurais. A política de inclusão 
a partir das organizações de seus integrantes produtores familiares pode ser decisiva e importante através das cooperativas ou associações, que no caso da Região Sul do Brasil vem apresentando um bom desempenho por obterem maiores possibilidades de sucesso nas atividades produtivas com o uso de técnicas e equipamentos para suas disseminações de forma solidária e unida no tocante ao uso otimizado por seus pares. Além de estarem incluindo a agricultura familiar no mercado, as cooperativas distribuem o capital social entre os agricultores o que lhes proporciona melhoria da qualidade de vida para as atividades empreendidas nas UFPs (ABRAMOVAY, 1999).

Silva e Homma (2007) concluem em seu estudo conduzido nos Projetos de Assentamentos no Sudeste Paraense que a sustentabilidade ainda é utópica. Os agricultores dependem da destruição dos recursos naturais, ultrapassando os limites legais, procedendo a venda ilegal da madeira, inclusive de castanheiras derrubadas de áreas impróprias, entre outros, cuja permanência está associada com os estoques de floresta remanescente. Muitos dependem de programas governamentais para garantir a sua sobrevivência, as atividades agrícolas apresentam baixa rentabilidade, fazendo com que poucos consigam sobreviver com estas atividades empreendidas nas UFPs. A venda de mão-de-obra, que também seria importante para garantir a sustentabilidade, encontra obstáculos na legislação trabalhista para garantir o seu aproveitamento extra propriedade. A sustentabilidade não está apoiada apenas nos requisitos técnicos e econômicos, mas apresenta dimensões que dependem do mercado de trabalho, de produtos e fatores de produção, da economia global, e que não são favoráveis à agricultura familiar pelos estudos já realizados nessas perspectivas.

Segundo Buainain e Guanziroli (2004), a diferenciação dos agricultores familiares está ligada à própria formação dos grupos ao longo de suas histórias, às heranças culturais, à experiência profissional de vida, ao acesso e à disponibilidade de um conjunto de fatores, entre os quais os recursos naturais, o capital humano e o capital social, que preconizam o sucesso ou a falência em suas atividades produtivas.

A agroecologia, na discussão de Altieri (2012), aparece como uma alternativa dentro do conceito de desenvolvimento sustentável na agricultura familiar e sobretudo nos assentamentos rurais, pois pode ir além da visão tecnicista dos agroecossistemas e da genética agronômica, contemplando a discussão das dimensões ambiental, social e cultural. Assim, a agroecologia surge a partir da constatação dos efeitos 


\section{GESTÃO \& SUSTENTABILIDADE}

AMBIENTAL

\section{¿unisul}

negativos ao meio ambiente e às populações rurais, ocasionados pela modernização das técnicas e a maior mecanização promovida pelo agronegócio, pois traz elementos de maior eficácia no aproveitamento dos recursos naturais buscando equilíbrio e pensando a sustentabilidade nas ações produtivas.

Nessa mesma perspectiva da agroecologia, a autora Primavesi (2006) afirma que o agricultor deixa de perguntar a outros "O que eu faço?" diante dos desafios no ambiente de produção e passa a questionar-se "Por que ocorre?". Pois o significado dessa reorientação do tipo de pergunta diante de um problema técnico, em seus cultivos nas propriedades familiares, por exemplo, promove mudanças de suas atitudes em relação às práticas na agricultura. Ao invés de receber técnicas préelaboradas, passa a observar, pensar e experimentar os meios e as formas de trabalhar menos impactantes para suas atividades produtivas. E é assim que ele se dá conta da sua importância na produção de alimentos, no respeito às leis ambientais, acreditando em si mesmo e protegendo conscientemente o meio ambiente.

\section{MATERIAIS E MÉTODOS}

\subsection{Local de Estudo}

O presente estudo foi realizado no município de Conceição do Araguaia, localizado precisamente no Sudeste do Estado do Pará, às margens do rio Araguaia. O município apresenta uma área territorial de $5.829 \mathrm{~km}^{2}$, a densidade demográfica de $7,81 \mathrm{hab} / \mathrm{km}^{2}$ e a população aproximada de 47.991 habitantes, distribuídos entre zona urbana e rural (IBGE, 2016).

A escolha da área de pesquisa foi realizada após uma série de leituras da Região Sudeste do Estado do Pará e sobre o conhecimento particular do autor na região. Nas revisões de literatura verificou-se que a maioria dos estudos estavam voltados para o município de Marabá e regiões circunvizinhas. Frente a isto, nossa atenção voltou-se para o município de Conceição do Araguaia, onde existe uma grande concentração de assentamentos rurais com pequenas unidades produtivas que investem, principalmente, na criação de bovinos.

A pesquisa contou com visitas agendadas a dez UFP - Unidades Familiares de Produção, cinco em cada Assentamento Rural, totalizando 10 entrevistas, através de 


\section{GESTÃO \& SUSTENTABILIDADE AMBIENTAL}

\section{¿UNISUl}

conversas com assentados e entrevistas semiestruturadas em dois assentamentos:

O Assentamento Rural Padre Josimo Tavares, advindo da desapropriação da antiga Fazenda Bradesco, mas ainda assim é chamada comumente pela comunidade em geral de "Assentamento Bradesco", com 800 UFP, e o Assentamento Rural Canarana, originado da desapropriação da Fazenda Canarana, com 258 UFP, com cinco unidades Familiares de Produção (UFP) em cada Assentamento rural que podem ser visualizadas na Figura 1.

Figura 1 - Sudeste do Pará - Área do município de Conceição do Araguaia e os seus Assentamentos, com destaque para os PAs Padre Josimo Tavares e Canarana.
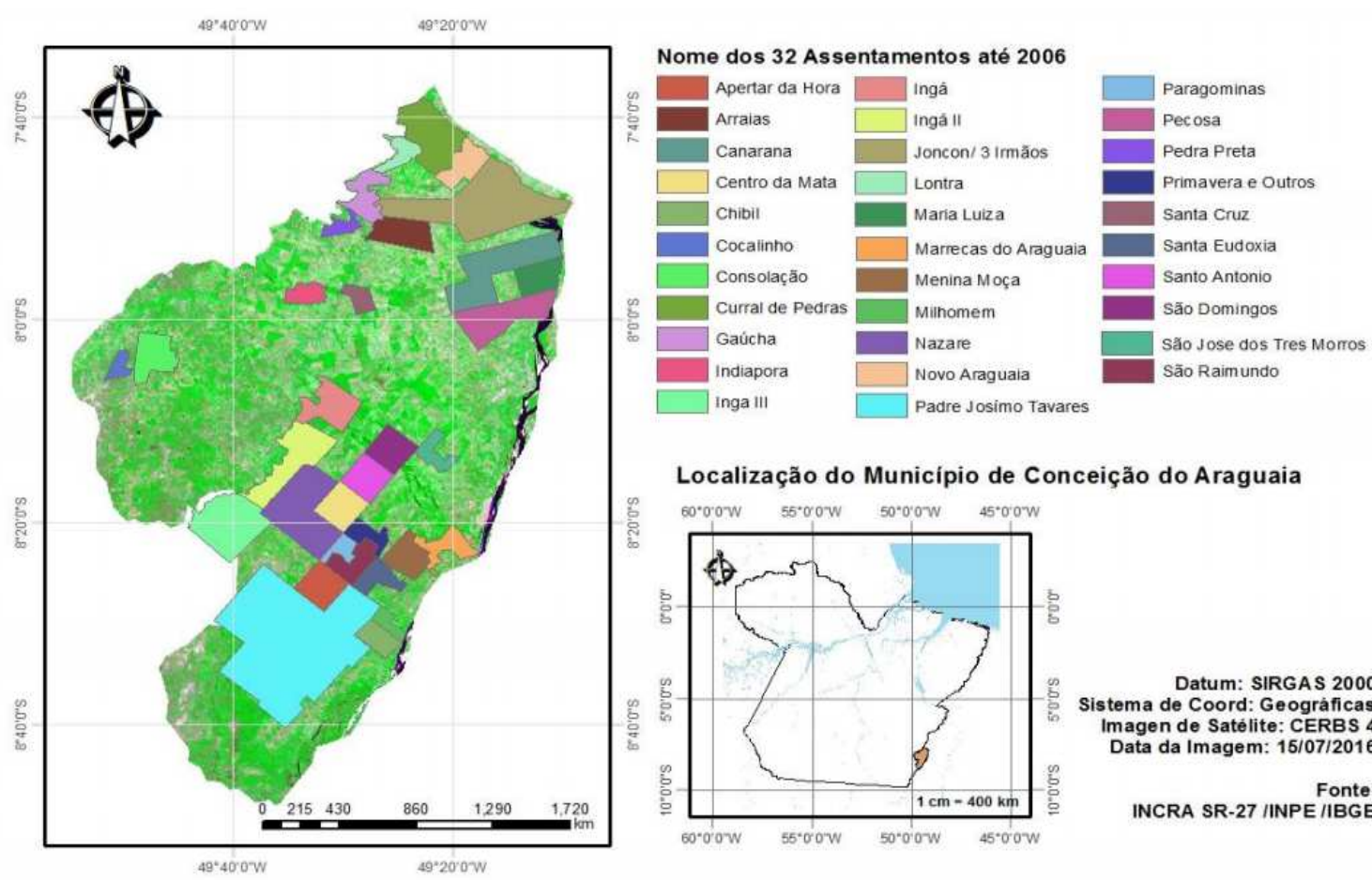

Localização do Município de Conceição do Araguaia
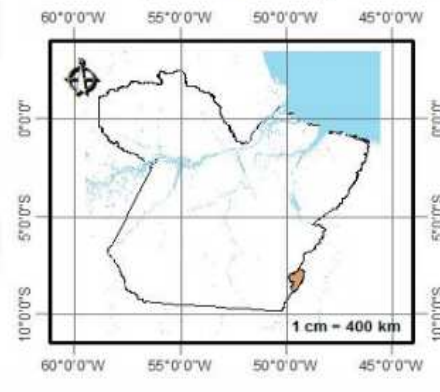

Datum: SIRGAS 2000
Sistema de Coord: Geográficas
Imagen de Satélite: CERBS 4
Data da Imagem: 15/07/2016
Fonte:
INCRA SR-27 /INPE /IBGE

Fonte: IBGE (2016) e INCRA/ Cartografia (2015). Com adaptações.

A definição desses dois assentamentos como amostragem da pesquisa deu-se a partir do conhecimento prévio adquirido da região e do estudo de Terence (2013), que salienta que nesses dois assentamentos são percebidas particularidades similares na organização dos membros participantes, sem hierarquização na sua ocupação, com um maior vínculo e conhecimento entre as famílias integrantes e uma maior diversificação das atividades produtivas, fazendo referência à apicultura com a produção de mel e à produção de polpas de frutas, que podem ser consideradas menos impactantes ao meio ambiente em relação a bovinocultura, que ainda é a mais difundida em todos os assentamentos rurais da região de Conceição do Araguaia. 


\subsection{Coletas de Dados}

As atividades de campo ocorreram no período de novembro de 2015 a março de 2016, utilizando-se de diários de campo para os registros de informações e à observação das paisagens dos assentamentos com o uso de imagens das atividades desenvolvidas. Foi feita a identificação dos produtores familiares a serem entrevistados, observação dos sistemas produtivos e cultivos, questionamentos acerca do entendimento dos agricultores quanto às suas visões da qualidade de vida de suas famílias, relação com o mercado, além de outras abordagens que foram pertinentes durante as entrevistas.

Esta pesquisa teve característica exploratória, com abordagem qualitativa e de coleta de dados bibliográficos, que auxiliou a discussão da realidade dos assentamentos rurais. Segundo Neves (1996), a pesquisa qualitativa costuma ser direcionada ao longo do seu desenvolvimento, além disso pode enumerar e medir eventos. Dela faz parte a obtenção de dados descritivos mediante contato direto e interativo do pesquisador com a situação do objeto de estudo.

Todas as entrevistas contaram com a participação do marido ou da esposa, considerados como chefes familiares, em algumas vezes com a participação simultânea destes e por vezes com o auxílio de informações também dos filhos, que estavam presentes nas propriedades na ocasião das entrevistas e que se dispuseram a fornecer informações ao pesquisador. Esses entrevistados tiveram suas identidades resguardadas e serão tratados por identificações codificadas ao estudo: EB1, EB2, EB3, EB4, EB5, EC1, EC2, EC3, EC4 e EC5. E para a correta interpretação dos códigos acima citados que estarão ao longo do estudo, estão representando as entrevistas realizadas, $\mathrm{EB}=$ Entrevista realizada no $\mathrm{PA} \mathrm{Pe}$. Josimo Tavares (Bradesco). EC: Entrevista realizada no PA Canarana. Logo EB1 $=1^{\text {a }}$ Entrevista realizada no PA Bradesco. E EC2 $=2^{\text {a }}$ Entrevista Realizada no PA Canarana, assim sucessivamente.

Esta pesquisa teve como amostragem uma composição convencional, ou seja, não foi levado em consideração o propósito de uma representatividade populacional desses assentamentos rurais, apesar de terem sido escolhidos de forma aleatória. As propriedades pesquisadas e pessoas entrevistadas seguiram um roteiro de questões 
semiestruturadas feitas para os seus chefes familiares, que ao concordarem em participar foram informados que teriam suas identidades mantidas em anonimato. As entrevistas foram realizadas buscando algumas características básicas desses entrevistados como: (i) o desenvolvimento de alguma atividade produtiva na UFP; (ii) a identificação de pelo menos um dos integrantes da família atuando nas atividades produtivas na UFPs; e (iii) os entrevistados oferecendo sua disponibilidade em receber o pesquisador e participar da investigação sobre a realidade da sustentabilidade nos assentamentos rurais.

\subsection{Análise de dados e os Indicadores de Sustentabilidade}

Foram construídos indicadores focando os atributos da sustentabilidade (produtividade, estabilidade e resiliência) para a dimensão da sustentabilidade ambiental. Esta escolha decorre da necessidade de identificar os aspectos de condições de sustentabilidade que foram observadas durante as visitas, bem como consideradas e inseridas no roteiro das entrevistas. Com base na proposta de Schultz, Barden e Laroque (2010) intitulada de "Cadeias Produtivas de Alimentos Orgânicos e Desenvolvimento Sustentável da Região do Vale do Taquari-RS" (2010), que utiliza uma metodologia para a avaliação das condições de sustentabilidade ambiental, econômica e sociocultural em propriedades rurais daquela localidade estudada.

Neste estudo foi realizada uma avaliação focada nas condições de sustentabilidade ambiental a partir dos atributos de produtividade ${ }^{6}$, estabilidade ${ }^{7} \mathrm{e}$ resiliência ${ }^{8}$ (SCHULTZ; BARDEN; LAROQUE, 2010), adaptados para avaliação da realidade percebida nos assentamentos rurais de Conceição do Araguaia. A adaptação dos indicadores indicadas neste estudo é provida da relação dos atributos de sustentabilidade com a dimensão ambiental e foi construída também a partir da experiência do primeiro autor que vem atuando ao longo de dez anos nas áreas dessa

6 É a capacidade de um agroecossistema gerar o nível desejado de bens e serviços, representa o valor de atributos como rendimentos ou ganhos em um tempo específico, como também ações de grupos em produzir de forma conservacionista. Em agroecossistemas as análises clássicas, por exemplo, se referem prioritariamente à quantidade de produto por unidade de área $(\mathrm{kg} / \mathrm{ha})(\mathrm{ALTIERI}, 2012)$.

7 Representa o equilíbrio dinâmico dos ecossistemas ao longo do tempo, onde após as perturbações sofridas sucede-se uma retroalimentação capaz de restabelecer o equilíbrio funcional do sistema com os parâmetros de bem-estar social (ALTIERI, 2012).

${ }^{8}$ Entendida como a capacidade de um ecossistema retornar à capacidade de manutenção das condições de vida de populações e espécies após a ocorrência de perturbações graves, ela pode ser observada na capacidade de restabelecer o equilíbrio econômico de uma unidade produtiva (ALTIERI, 2012). 
pesquisa, tanto em visitas técnicas como educador de Cursos Técnicos e superiores das Ciências Agrárias do Instituto Federal do Pará (IFPA), em assentamentos rurais de Conceição do Araguaia. Sendo assim, foram definidos os respectivos indicadores e variáveis, que serviram para a obtenção dos resultados e discussões deste artigo.

A análise dos indicadores já mencionados da dimensão ambiental, pela percepção e falas dos pequenos produtores nos assentamentos investigados, foram tomadas pela constatação da existência de algumas práticas conservacionistas para atender com isso uma perspectiva do atributo de produtividade sustentável. Outra análise realizada, de como se percebe as paisagens das propriedades em constantes transformações, foi relacionada com o atributo de estabilidade para se obter uma menção de rápida ou lenta transformação do espaço produtivo como parâmetro da realidade. Na última avaliação foi realizado o levantamento da diversidade produtiva das UFPs para confrontar com a resiliência, ou seja, com a capacidade do ecossistema das UFPs de se recuperar. Com isso foram definidos esses indicadores e daí avaliada a sustentabilidade ambiental nos assentamentos rurais pesquisados.

Utilizou-se o diário de campo que, segundo Vianna (2007), é um instrumento essencial para registrar as observações realizadas no campo e as ideias que surgirem durante as observações em que os sentidos da visão e da audição e o espírito estão em alerta, podendo oferecer valiosas informações na coleta de dados em momentos subsequentes do trabalho. Aliado a isso, foram utilizados os registros fotográficos para auxiliar as interpretações da paisagem que, conforme Costa (2004) comenta, é um instrumento que agrega mais ricas informações de análise do ambiente estudado e auxilia a composição da pesquisa de campo.

As informações foram obtidas a partir das entrevistas, dos diários de campo e das imagens fotográficas para análise da realidade produtiva no contexto ambiental encontrado nos assentamentos analisados. Salienta-se que os dados das entrevistas foram analisados sob a ótica dos indicadores, a partir das questões que compõem a própria entrevista semiestruturada. Realizou-se a análise dos indicadores considerando as informações levantadas nas entrevistas semiestruturadas e observações de campo. 
4 RESULTADOS E DISCUSSÃO

\subsection{Análise de condições de sustentabilidade ambiental nos assentamentos rurais}

A análise dos indicadores de sustentabilidade ambiental e as variáveis percebidas nos assentamentos rurais estudados são discutidas a seguir.

\subsubsection{Práticas Conservacionistas}

O Atributo investigado aqui foi o da Produtividade, nas propriedades visitadas foi utilizado como indicador as práticas conservacionistas, sendo que as variáveis observadas: 1. Práticas de manejo do solo; 2. Práticas de conservação dos recursos hídricos; 3. Reciclagem e destino de lixo (BARDEN et al. 2011). Destaca-se as práticas de manejo conservacionistas nas atividades de produção agrícolas e pecuárias que são desenvolvidas na UFPs, como o uso de adubo orgânico a partir da coleta de fezes dos animais e da compostagem feita com lixo orgânico, evitando o uso de agrotóxicos e do fogo. Contudo, é possível perceber a proteção de nascentes, o plantio direto, consórcio de culturas, adubação verde e inserção de algumas variedades resistentes a pragas e intempéries.

Na variável de práticas de manejo do solo, de acordo com Altieri (2012) a principal variável que indica um solo fértil é sua capacidade maior de produzir e diversificar nessas produções espécies vegetais. Ainda de acordo com este autor, salienta-se que a qualidade e a saúde do solo têm referência a um amplo conjunto de propriedades como, por exemplo, os nutrientes em quantidade suficientes - nitrogênio, potássio, fósforo e outros -, o pH, matéria orgânica do solo, propriedades físicas como densidade e textura do solo, entre outros aspectos que qualificam e caracterizam o solo.

Para Gliessman (2012), a agricultura tradicional, caracterizada pelo uso intensivo do solo, plantio de monoculturas, aplicação de fertilizantes sintéticos, irrigação e controle químico de pragas, pode resultar em degradação do meio ambiente e em drástica redução da área de ecossistemas nativos. Diminuindo os teores de matéria orgânica do solo, a maior parte da vida microbiana não sobrevive, pois fica sem alimento. A matéria orgânica e os microrganismos são importantes para o solo, prevenindo o desagregamento de suas partículas, a compactação e o 
endurecimento. Por isso, com a utilização de insumos químicos, o solo tem sua capacidade de produção reduzida e fica dependente quimicamente da agricultura convencional ou tradicional (PRIMAVESI, 2006).

Para a manutenção e maior eficácia sustentável nos manejos de solo, existem algumas alternativas como a adubação verde e o plantio direto. Segundo Espíndola et al. (1997), a adubação verde pode reduzir ou até eliminar o uso de fertilizantes minerais nitrogenados, baixando os custos de produção. São inúmeros os benefícios dessa modalidade mais sustentável, como o ganho de matéria orgânica no sistema produtivo, proporcionando melhoria das propriedades físicas, químicas e biológicas do solo. A adubação verde consiste no uso de plantas (normalmente leguminosas) para serem incorporadas no solo, com a finalidade de melhorar o valor de nutrientes para agricultura. Esta é uma técnica agroecológica diferente da compostagem, que transfere os adubos mineralizados para o sistema de produção.

O plantio direto já é uma técnica conservacionista de cultivo, no qual o plantio é efetuado sem as etapas de preparo convencionais como a aração e a gradagem. Nesta técnica é necessário manter o solo sempre coberto por plantas em desenvolvimento e por resíduos vegetais. A cobertura tem por finalidade proteger o solo do impacto direto das gotas da chuva na lixiviação e das erosões hídricas e eólica, e definido como processo de semeadura em solo não removido em contato com a terra (RAlJ et al., 1996),

Nas entrevistas realizadas, com exceção de uma propriedade no Assentamento Padre Josimo Tavares e duas no Assentamento Canarana, as outras sete UFP utilizam pelo menos uma vez por ano a aragem e gradagem como forma de preparar o solo para a posterior plantação. Em uma propriedade no assentamento Canarana foi interessante o comentário de um produtor familiar acerca desse assunto:

\footnotetext{
"Pois aumentando o cuidado com a terra e não agredindo ela, teremos mais produção para a gente agora e para o futuro dos que ficaram aqui para prosseguir a vida, Deus nos deu uma terra tão boa porque a gente tem que acabar com ela? Devemos fazer nossa parte" (EC3, 18/12/2015, p. 3).
}

Nesse relato fica evidente a tentativa desse produtor familiar em promover ações que conservem os recursos naturais, ou seja, alternativas produtivas mais sustentáveis com o solo para futuras gerações poderem fazer uso. 
Quando questionados sobre essa prática de manejo do solo, os que afirmaram a utilização com maquinário comentam que se pudessem utilizar mais o fariam, pois acreditam que são benéficas para a agricultura e o aumento da produção. Não avaliam esse tipo de manejo como prejudicial numa média e longa avaliação de ciclos produtivos, não fazendo a consorciação e muito menos a rotação de culturas como alternativas produtivas e de maior incorporação de nutrientes importantes para o solo e assim uma maior longevidade produtiva desses solos. Um dos entrevistados diz que "utiliza o trator todas as vezes para ajeitar o solo para o plantio, pagamos a hora do trator de um vizinho" (EB2, 21/11/2015, p. 4).

É interessante salientar que não é perceptível na maioria das UFP a sensibilização e cuidado com o manejo do solo para a sua conservação e redução impacto ambiental a esse bem tão precioso às suas atividades produtivas. Foi percebido em duas propriedades no Assentamento Canarana que essa sensibilização é trabalhada a maior diversidade de espécies vegetais nas atividades produtivas da fruticultura para aumentar a longevidade e sustentabilidade dos solos, diferente de todas as outras UFP pesquisadas. Estudos agronômicos chegam à conclusão de que o aumento da diversidade de espécies vegetais contribui para melhoria da exploração dos recursos produtivos, menor incidência de doenças patogênicas, menor ação de herbívoros, fazendo com que a produção seja maior por área e aumentando a resistência contra as intempéries do clima (ALTIERI, 2012).

Souza e Fialho (2003) consideram que a consorciação e rotação de culturas tem muitas vantagens em relação aos monocultivos, como o de promover maior estabilidade da produção, melhorar a exploração de água e nutrientes, a utilização da terra, a utilização da força de trabalho nas UFP, aumentar a eficiência no controle de invasoras e a proteção do solo contra erosão e disponibilizar mais de uma fonte alimentar e de renda para os produtores. Nesse contexto, a mandioca é importante como cultura pelo seu ciclo vegetativo longo, crescimento inicial lento, variedades com hábito de crescimento ereto e vigor de folhagem médio, caracterizando as possibilidades de consórcio, principalmente com culturas anuais. Vale salientar que a cultura da mandioca foi a maior atividade agrícola das UFP constatada nas visitas aos assentamentos rurais Padre Josimo Tavares e Canarana em Conceição do Araguaia. Numa perspectiva futura para que as atividades empreendidas obtivessem uma maior eficácia, a consorciação com outras culturas nos assentamentos poderia ser uma 
alternativa interessante como citado por Souza e Fialho (2003), mas em nenhuma das UFPs visitadas essa modalidade de produção é desenvolvida pelos pequenos produtores.

A variável de práticas de conservação de recursos hídricos foi observada que em todas as UFP, nas quais estavam disponíveis fontes de água para consumo e/ou produção agropecuária, sendo estas protegidas.

Os estudos desenvolvidos até o momento, como o de Markenwitz et al. (2004), vêm demonstrando que as mudanças no uso da terra na Amazônia induzem a graves mudanças na hidrologia dos corpos hídricos dessa região. A prática de cortar e queimar a vegetação da floresta para preparar a terra tende a aumentar temporariamente a entrada de nutrientes nos solos, prejudicando a qualidade da água de toda região.

Foi perceptível essa prática, de cortar e queimar a vegetação da floresta para preparar o solo para o plantio, em todas as UFP levantadas, salvo duas propriedades no Assentamento Canarana que utilizavam o plantio direto e o consórcio de espécies e a roça manual como limpeza das áreas próximas às fontes d’água.

O acréscimo na entrada de nutrientes no solo a partir da combustão da biomassa e do aumento nas taxas de decomposição de matéria orgânica, além da redução na absorção de nutrientes, com a eliminação da vegetação, promovem aumento na concentração de nutrientes nos corpos hídricos que drenam áreas desflorestadas. Portanto, os fluxos de nutrientes dos sistemas terrestres para os corpos hídricos podem ser progressivamente alterados com a dinâmica de crescimento da vegetação secundária e os tipos de práticas agrícolas empregadas (FIGUEIREDO et al., 2006). O uso do fogo como prática recorrente do preparo do solo e controle de invasoras é um fator influenciador nesse processo, pois os nutrientes podem ser transportados pelas cinzas e gases (KAUFFMAN et al., 1998).

No meio rural é perceptível que os resíduos líquidos provenientes da lavagem de utensílios domésticos e roupas, segundo Bazzarela (2005), trazem efluentes com grandes concentrações de sabões, nutrientes como o fósforo, nitrogênio, detergentes, óleos e graxas, e material orgânico que não se decompõem, podendo contaminar assim o solo e as águas subterrâneas, que vão posteriormente ser captados através de poços pelos produtores para consumo humano ou para as atividades produtivas na agropecuária. $O$ esgoto doméstico na maioria dos assentamentos do Brasil e nos 
assentamentos estudados tem tratamento e destino inadequados. Esse tipo de contaminação por efluentes de atividades domésticas foi constatado em todas as UFPs pesquisadas. Nenhuma propriedade faz uso de, por exemplo, uma fossa séptica, que seria uma alternativa viável para esses resíduos líquidos.

Todas as propriedades contaminam o solo e os seus recursos hídricos. Quando questionados por que não se preocupam em fazer uma fossa séptica, em sua maioria disseram desconhecer a importância de seu uso e não foram sensibilizados ou cobrados por nenhuma autoridade para a construírem. Em oito das dez propriedades pesquisadas evidenciou-se a presença da captação de águas subterrâneas por meio de poço semiartesiano, provavelmente contaminadas pela sua própria ação com os resíduos líquidos. Sem os devidos cuidados, somente em duas propriedades isso não foi identificado (DIARIO DE CAMPO, 18/12/2015a 18/12/2015b).

Para Ribeiro e Rooke (2010), o sistema de esgoto foi desenvolvido para afastar a possibilidade de contato com dejetos humanos e animais com a população, com as águas de abastecimento, com vetores de doenças e alimentos. Conforme a ONU (2013), dos mais de 7 bilhões de habitantes da população mundial, mais de 2,6 bilhões, aproximadamente $40 \%$, não têm acesso aos esgotamentos sanitários. Ainda segundo a ONU (2013), nas áreas rurais o problema é ainda maior devido ao esgotamento sanitário ser depositado diretamente no solo ou em corpos de água, sem o devido tratamento. Em propriedades rurais, a melhor maneira de se tratar o esgoto seria com a utilização de fossas sépticas, que são unidades simples de tratamento fundamentais no combate de doenças, verminoses, pois evitam o lançamento dos dejetos diretamente no solo e nos cursos d'água.

No que permeia a variável de indicador de reciclagem e destino de lixo foi observado que nas UFP como a exemplo das entrevistas realizadas (EC3, $18 / 12 / 2015$, p. 2) e (EB4, 23/11/2015, p. 1) nenhum dos produtores recicla seus resíduos e sete dos entrevistados queimam seu lixo e não criam alternativas que minimizem os impactos ambientais produzidos pelo seu próprio lixo, três produtores familiares - um no assentamento Padre Josimo Tavares e dois no assentamento Canarana -, fazem uso da compostagem proveniente do lixo orgânico. Os demais resíduos sólidos são armazenados e posteriormente levados pelos próprios produtores para o local de recolhimento de lixo urbano da cidade de Conceição do Araguaia. 


\section{GESTÃO \& SUSTENTABILIDADE} AMBIENTAL

\section{¿Unisul}

De acordo com Razzolini e Gunther (2008), o saneamento básico contribui decisivamente para a qualidade do ambiente e da saúde. Existem alternativas de grupos de pequenos produtores em parceria com prefeituras e ou cooperativas de catadores de lixo seletivo que podem criar meios eficazes para evitar as contaminações de solo e água nos assentamentos rurais. As associações de produtores e ou cooperativas dos assentamentos se organizariam para transportar o lixo para aterros sanitários e receptores de lixo seletivo para reciclagem.

Em locais onde é verificada a inexistência ou esgotamento sanitário precário, a disposição de resíduos sólidos a céu aberto provoca a proliferação de insetos e roedores que são vetores e agentes de contaminação e que podem disseminar e alcançar as fontes de água e os reservatórios de armazenamento e, consequentemente, gerar doenças infecciosas relacionadas com excretas, lixo e vetores que podem atingir a população que fica exposta. Isso foi evidenciado com um dos entrevistados (EB4, 23/11/2015, p. 1), que já teve infecções intestinais várias vezes e percebe na sua propriedade, em algumas áreas alagadas com águas da lavagem de roupa e resíduos líquidos e sólidos do banheiro, áreas de contaminação, com vetores da dengue e outras doenças infecciosas.

Conforme a sua pesquisa, Bertuzzi (2012) conclui que o esterco para compostagem é uma forma de reciclagem dos materiais, todavia percebe-se que o objetivo de tal prática é agregar fertilidade ao solo e com isso melhorar e aumentar a produtividade, contribuindo para o equilíbrio e a sustentabilidade da atividade produtiva. Com a atividade da bovinocultura que é praticada nas UFPs essa ferramenta de reciclagem poderia ser desenvolvida, no entanto em nenhuma propriedade visitada constatamos essa prática.

\subsubsection{Paisagem da propriedade}

Baseada na pesquisa de Barden et al. (2011) Com o atributo de Estabilidade, foi observada como indicador a paisagem das unidades familiares de produção dos assentamentos visitados e as variáveis foram: 1. área de preservação permanente e reserva legal; 2. diversidade da paisagem. Na pesquisa dos dados levantados, tomamos as informações relatadas nas entrevistas dos assentados, bem como a observação feita a campo nos diários de campo. 

AMBIENTAL

\section{Unisul}

Conforme Altieri (2012), um ponto importante na análise e observação da diversidade do agroecossistema é a descrição da situação da mata nativa, pois a preservação de matas, principalmente junto a fontes de água, é considerável com relação ao impacto sobre a sustentabilidade de um agroecossistema, que tem relação com atividades produtivas num determinado ambiente.

Na variável Área de Preservação Permanente (APP) e Reserva Legal (RL), que compõe o indicador paisagem da propriedade, registrou-se nos diários de campo, a exemplo das visitas realizadas as UFP dos assentamentos estudados (21/11/2015a e 11/12/2015b), que em média $25 \%$ das áreas totais das propriedades visitadas são cobertas com mata nativa e destinada a APP ou RL.

Segundo o novo Código Florestal Brasileiro, Lei 12.727/12 de 18 de outubro de 2012, as APPs, ou áreas de preservação permanente, são margens de rios, cursos d'água, lagos, lagoas e reservatórios, topos de morros e encostas com declividade elevada, cobertas ou não por vegetação nativa, com a função ambiental de preservar os recursos hídricos, a paisagem, a estabilidade geológica, a biodiversidade, o fluxo gênico de fauna e flora, e de proteger o solo e assegurar o bem-estar da população humana. São consideradas áreas mais sensíveis e sofrem riscos de erosão do solo, enchentes e deslizamentos. A reserva legal é uma área localizada no interior da propriedade ou posse rural que deve ser mantida com a sua cobertura vegetal original (BRASIL, 2012).

Nas observações dos diários de campo e do uso das entrevistas fica evidente que a grande maioria dos produtores não sabia sequer o que seria Área de Preservação Permanente e Reserva Legal, salvo dois entrevistados do Assentamento Canarana e em um destes diz o seguinte:

\footnotetext{
"Olha, as áreas de reserva legal são previstas na lei e a preservação permanente são as matas ciliares por exemplo. Eu tenho um córrego e tenho muito esse cuidado de não chegar desmatando essas áreas de preservação" (EC2, 11/12/2015, p. 3).
}

É perceptível nas entrevistas realizadas nas UFP visitadas a ausência da RL, com exceção dos dois assentados da Canarana, que faziam reserva em quase toda área da UFP, pois trabalhavam produzindo mel pela atividade da apicultura e diversificavam a produção de frutas, sem necessitar desmatar. Todas as propriedades têm em suas unidades familiares dos assentamentos investigados áreas de matas 


\section{GESTÃO \& SUSTENTABILIDADE} AMBIENTAL

\section{unisul E}

que são preservadas, sendo variável o seu tamanho de propriedade para propriedade.

Os entrevistados do Assentamento Padre Josimo Tavares comentaram que existe uma reserva legal desde a sua criação que dá o passivo ambiental ao assentamento, que é protegido pelo IBAMA como é ratificado pelo entrevistado no estudo:

\footnotetext{
"Eu tenho na margem do corgo, dois alqueires de mata que não derrubo, só que aqui no nosso assentamento nós tem nossa reserva, que serve como a área de reserva legal, nesse caso nós pode utilizar ela toda porque a nossa reserva já abastece, já sustenta nosso assentamento" (EB1, 21/11/2015, p. $4)$.
}

Quanto à variável diversidade da paisagem percebeu-se no momento das entrevistas a ocorrência de várias espécies nativas encontradas e comentadas pelos produtores rurais nas APPs e RLs - ipês rosa e amarelo, jatobás, castanheiras, copaíba; de animais como tatus, antas, onças e macacos entre outros. Como afirma o entrevistado que em sua UFP "ainda temos o ipê, jatobá, amarelão e o tatu que eu lembro agora, acho que são essas" (EB3, 22/11/2015, p. 5). Pode-se constatar que a paisagem ainda é rica e diversa nos assentamentos visitados e que precisa de cuidados nas atividades produtivas para a sua longevidade e melhor aproveitamento dos recursos naturais.

O atributo tratado aqui de paisagem, conforme Santos (1999), é a percepção da dimensão ambiental, o que chega aos sentidos, ou seja, paisagem é tudo aquilo que vemos. A paisagem pode ser definida como o processo pelo qual o ser humano se informa dos objetos e transformações manifestadas ao seu redor.

Para Sampaio (2008), no processo interativo do homem com o meio ambiente na região amazônica, a demanda por mais espaço físico em decorrência da pressão demográfica tem levado grandes áreas de floresta a serem desmatadas e abandonadas ou substituídas por sistemas intensivos de produção, alterando ecossistemas homogêneos e compondo uma grande diversidade de configurações espaciais. A autora ainda considera que a substituição da floresta por pastagem ameaça a biodiversidade e dificulta a produção da agricultura familiar, uma vez que reduz a área para o plantio, impedindo a implantação de roças e reduzindo a diversidade das atividades de produção em assentamentos rurais na região do sudeste paraense. Isso pode ser evidenciado nas entrevistas em que a atividade da bovinocultura é soberana em oito propriedades pesquisadas, aumentando a área de 
cultivo de pasto e diminuindo as áreas de plantio diversificado de outras culturas agrícolas, que poderiam ser benéficas aos produtores familiares e assim pressionando a sustentabilidade nos assentamentos rurais estudados.

Com o cenário observado nos assentamentos rurais no sudeste paraense, a paisagem observada é de devastação, com pastagem de cultivares em áreas já muito degradadas em sua maioria; poucas áreas de mata, com árvores esparsas que restam de uma transição de biomas do Cerrado e da Amazônia devido principalmente ao advento da pecuária. Nesse sentido, seria interessante uma ação organizada com engajamento de instituições como a EMATER/PA, INCRA, universidades, institutos, prefeituras, organizações não governamentais, cooperativas e associações de assentamentos rurais para a conservação da paisagem e a mitigação ou minimização do desflorestamento dessa região, buscando reverter a situação encontrada nas UFP. 4.1.3 Diversificação da Produção

Baseado no estudo de Barden et al. (2011) neste item, que contempla o atributo de resiliência, o indicador que se trabalha é o de diversificação da produção (sistema produtivo), as variáveis trabalhadas são: 1. espécies vegetais e animais como produção; 2. práticas de consorciação, rotação e integração de culturas. Aqui são enfocados as espécies vegetais e animais produzidas nas UFP e as práticas de consorciação, rotação e integração de culturas e de atividades implementadas.

Na variável espécies vegetais e animais como produção, considerando-se todas as propriedades visitadas, a espécie animal mais criada pelos produtores familiares é a dos bovinos com uma forte tendência na produção da carne, encontrada em $80 \%$ das UFP visitadas. A espécie de vegetal cultivada com maior representação foi a mandioca, presente em $80 \%$ das propriedades e sendo o carro-chefe em três propriedades. Também pode ser percebida uma diversidade de outras espécies cultivadas em função da venda de polpa de frutas em duas UFP do Assentamento Canarana, com foco produtivo para venda nas feiras e para os atravessadores, assim como o milho e as hortaliças produzidas em geral para consumo interno.

Entre as espécies vegetais cultivadas para a comercialização foi observado uma diversidade de produtos e entre os principais apontados pelos entrevistados (EB2, 21/11/2015 p.3) e (EC5, 18/12/2015 p.2) estão a mandioca, já citada, arroz, milho, alface, feijão, caju, cupuaçu, açaí, manga, acerola, limão, tomate, entre outros. 
Vale ressaltar que todas as mudas e sementes são adquiridas por meio de troca entre os integrantes do assentamento rural e vizinhos, e muito raramente busca-se em casas especializadas na cidade de Conceição do Araguaia.

A diversidade na produção é um aspecto decisivo quando se busca analisar a sustentabilidade do agroecossistema. Gliessman (2012) salienta que nos ecossistemas naturais a diversidade é mais frequente que em agroecossistemas, diz ainda que na agricultura sustentável um dos desafios é reincorporar a diversidade na paisagem agrícola e manejá-la com efetividade.

Na variável práticas de consorciação, rotação e integração de culturas, Darolt (2000, p.221) comenta que em se tratando de atividades produtivas de base sustentável "o que se busca é um equilíbrio que atenda a rotação de culturas nas unidades de produção, para a sazonalidade de produtos e à demanda dos consumidores". Com essa perspectiva constatou-se que somente duas propriedades no Assentamento Canarana fazem uso da prática de consorciação como a percebida no fragmento da entrevista:

"Com certeza, mas o que mais é importante nessa questão da variedade das frutas é que o consórcio promove a florada em épocas diferentes beneficiando a produção das abelhas ao longo do ano" (EC2, 11/12/2015, p. 2).

Em $80 \%$ das propriedades estudadas não se faz uso de rotação de culturas e/ou consorciação. Uma propriedade no Assentamento Padre Josimo Tavares e outra no Assentamento Canarana utilizam a integração de culturas, com a bovinocultura utilizando a mandioca e o milho como suplementação nutricional dos animais, propiciando uma diminuição dos custos, a reciclagem dos nutrientes para o plantio da mandioca e do milho, aumentando a sustentabilidade do empreendimento da UFP, como afirma o entrevistado "planto milho pra suplementar os animais, para ficarem gordos" (EB4, 23/11/2015, p. 3).

Segundo Costa (2004), a rotação de culturas é uma prática importante para a resiliência, eficiência e autossuficiência dos agroecossistemas. Ainda conforme este autor em suas observações em campo, a rotação de culturas é feita basicamente a partir dos conhecimentos empíricos dos produtores rurais, pois buscam evitar o plantio de uma mesma espécie em sucessão trazendo benefícios ao solo e o aumento da produção. 

AMBIENTAL

\section{¿UISUl}

Darolt (2000) afirma que em se tratando de produção animal esta deve estar sempre que possível integrada com a produção vegetal, visando a otimização da reciclagem dos nutrientes (dejetos dos animais, biomassa vegetal), reduzindo a dependência de insumos externos, como rações, adubos orgânicos e outros, potencializando os benefícios diretos e indiretos da integração dessas atividades. Verona (2008) define que intensificação no trabalho de integração das atividades de produção animal e vegetal seria fundamental para potencializar a produção dos sistemas agrícolas familiares. Como exemplos cita-se o plantio de frutíferas e a atividade apícula desenvolvida no Assentamento Canarana (Figura 2) e a produção de galinhas coloniais e de bovinos de leite que contribuem com matéria orgânica para as atividades agrícolas visualizadas no momento das entrevistas em duas propriedades EC2 e EC3 de 11/12/2015.

Figura 2 - Plantio de culturas frutíferas com a integração da apicultura

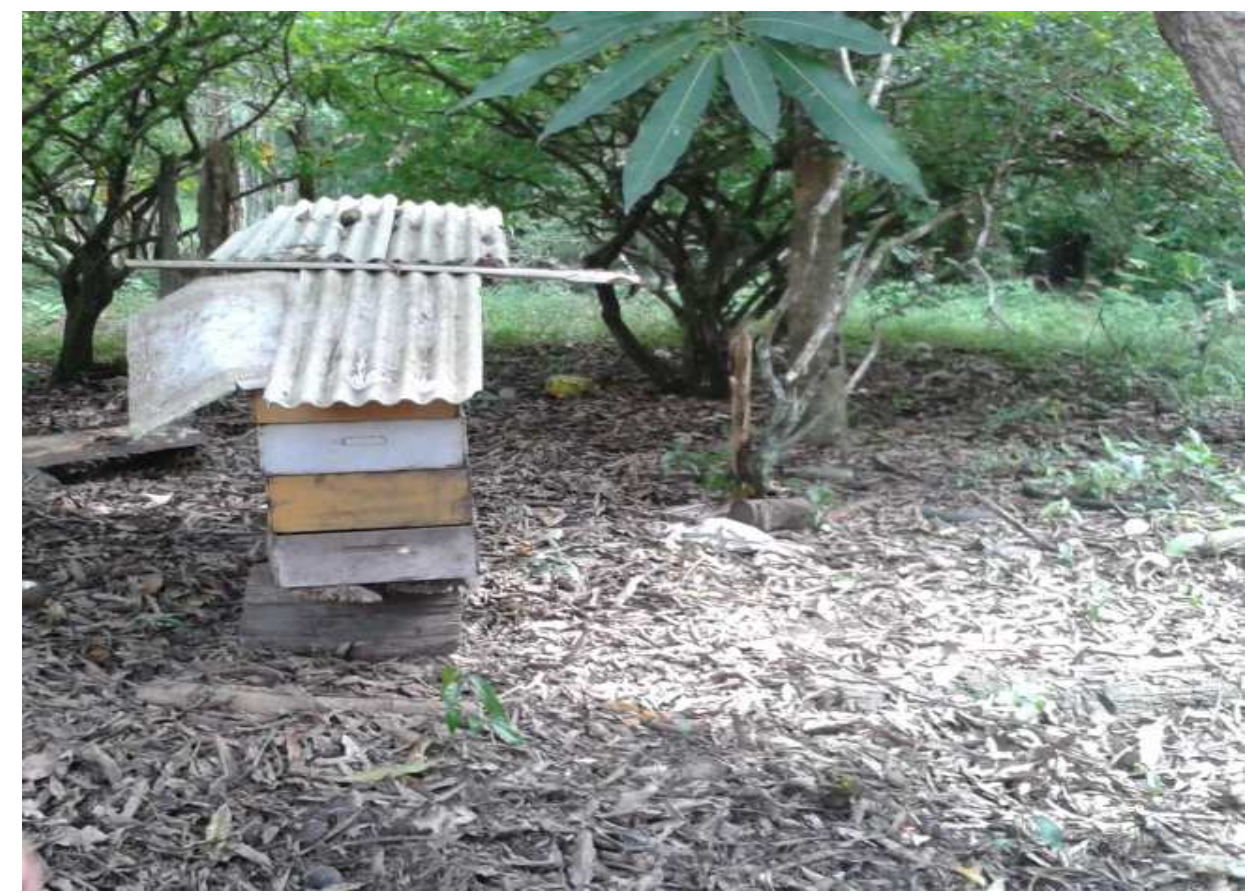

Fonte: Elaboração dos autores, 2015.

As alternativas de Costa (2004) e Darolt (2000), entre outros que discutem a realidade da diversidade produtiva e as formas estratégicas de melhorias das condições de enfrentamento da degradação do meio ambiente em assentamentos rurais, são, em síntese, possíveis soluções para as condições de manutenção dos recursos naturais das áreas produtivas para as famílias trabalhadoras nas UFP. 


\section{GESTÃO \& SUSTENTABILIDADE AMBIENTAL}

\section{১unisul}

Uma síntese dos resultados obtidos para a dimensão ambiental a partir das

entrevistas e observações realizadas nos assentamentos rurais visitados é apresentada no quadro 1.

Quadro 1 - Resumo da Análise das variáveis das condições de sustentabilidade da dimensão ambiental realizada nos Assentamentos Padre Josimo Tavares e Canarana, município de Conceição do Araguaia-PA.

\begin{tabular}{|c|c|c|c|}
\hline Atributos & Indicadores & Variáveis & Resumo da análise das variáveis \\
\hline Produtividade & $\begin{array}{c}\text { Práticas } \\
\text { conservacionistas }\end{array}$ & $\begin{array}{l}\text { 1. Práticas de } \\
\text { manejo do } \\
\text { solo; } \\
\text { 2. Práticas de } \\
\text { conservação } \\
\text { dos recursos } \\
\text { hídricos } \\
\text { 3. Reciclagem } \\
\text { e destino de } \\
\text { lixo }\end{array}$ & $\begin{array}{l}\text { Observou-se que na relação do atributo de } \\
\text { produtividade com as variáveis desse } \\
\text { indicador, os assentados em sua maioria, } \\
\text { não fazem uso de ações menos danosas ao } \\
\text { solo e à conservação dos recursos hídricos; } \\
\text { dois produtores trabalham cientes de suas } \\
\text { responsabilidades no uso dos recursos } \\
\text { naturais nas UFP investigadas. Não existe } \\
\text { reciclagem de resíduos sólidos e o destino } \\
\text { do lixo não é adequado, o fogo é largamente } \\
\text { utilizado pela grande maioria dos } \\
\text { produtores; }\end{array}$ \\
\hline Estabilidade & $\begin{array}{l}\text { Paisagem da } \\
\text { propriedade }\end{array}$ & $\begin{array}{l}\text { 1. Área de } \\
\text { preservação } \\
\text { permanente e } \\
\text { reserva legal; } \\
\text { 2. Diversidade } \\
\text { da paisagem }\end{array}$ & $\begin{array}{l}\text { A maioria dos produtores desconhece o que } \\
\text { é APP e RL, citam que no PA Padre Josimo } \\
\text { Tavares existe uma Reserva Legal que é } \\
\text { protegida pelo IBAMA, é considerada como } \\
\text { passivo deste assentamento; no PA } \\
\text { Canarana não existe essa mesma área de } \\
\text { RL. A legislação de APP e RL é } \\
\text { desrespeitada nas UFP pesquisadas; mas } \\
\text { existe uma média de } 25 \% \text { de mata nativa } \\
\text { nos dois assentamentos estudados. A } \\
\text { diversidade da paisagem em relação ao } \\
\text { atributo de estabilidade nos assentamentos } \\
\text { é de transição de poucas áreas de floresta } \\
\text { para enormes áreas de pastagens na } \\
\text { maioria das propriedades visitadas, pela } \\
\text { atividade da bovinocultura, salvo em duas } \\
\text { propriedades que conservam uma } \\
\text { diversidade florestal considerada. }\end{array}$ \\
\hline Resiliência & $\begin{array}{l}\text { Diversificação da } \\
\text { Produção }\end{array}$ & $\begin{array}{l}\text { 1. Espécies } \\
\text { vegetais e } \\
\text { animais como } \\
\text { produção; } \\
\text { 2. Práticas de } \\
\text { consorciação, } \\
\text { rotação e } \\
\text { integração de } \\
\text { culturas }\end{array}$ & $\begin{array}{l}\text { Com a análise do atributo de resiliência } \\
\text { como indicador a partir de suas variáveis, } \\
\text { foram percebidos que a espécie vegetal } \\
\text { mais cultivada, é a mandioca, presente em } \\
80 \% \text { das propriedades, a criação animal } \\
\text { mais difundida nos assentamentos é dos } \\
\text { bovinos em } 80 \% \text { dos assentamentos } \\
\text { visitados, desenvolvem essa prática } \\
\text { produtiva. Em } 80 \% \text { das propriedades } \\
\text { estudadas não há uso de rotação de culturas } \\
\text { e/ou consorciação e somente } 20 \% \\
\text { propriedades se faz. Uma propriedade no } \\
\text { assentamento Padre Josimo Tavares e outra } \\
\text { no assentamento Canarana utiliza a } \\
\text { integração da cultura produtiva da } \\
\text { bovinocultura com a mandioca e milho. }\end{array}$ \\
\hline
\end{tabular}

Fonte: Elaboração dos autores, 2015. 
Com isso a análise consistiu em apresentar a correlação dos dados coletados por meio das entrevistas e dos diários de campo com os parâmetros dos indicadores e os atributos de sustentabilidade nos assentamentos investigados, mas destaca a importância que todas as UFPs estão preocupadas com suas condições de sustentabilidade ambiental, pois podem obter uma maior qualidade de vida e servirem como ponto de partida para sensibilizar os demais produtores e outros assentamentos rurais.

\section{CONSIDERAÇÕES FINAIS}

Pautando-se nos resultados obtidos neste estudo constata-se a fragilidade ambiental nos assentamentos rurais investigados, em relação aos indicadores e atributos de sustentabilidade levantados.

Observou-se que os assentados, em sua maioria, fazem uso de ações impactantes ao solo e à conservação dos recursos hídricos. Somente dois produtores mostraram-se conscientes de suas responsabilidades quanto aos recursos naturais nas UFP. A reciclagem de resíduos sólidos é pífia e o destino do lixo inadequado. $O$ fogo ainda é utilizado pela maioria dos produtores.

O uso do solo e dos recursos hídricos nos dois assentamentos pode melhorar seus indicadores em relação ao uso sustentável. Nesse sentido, a prática dos dois produtores que observam as técnicas de uso sustentável dos recursos naturais nas UFP pode ser um bom começo para incentivar a melhoria dos indicadores ambientais.

Por tudo, fica evidente que as UFPs do Assentamento Canarana têm melhores condições de sustentabilidade do que o Assentamento Padre Josimo Tavares, por intermédio da comparação dos indicadores avaliados. Torna-se perceptível uma tendência das UFPs para as atividades produtivas de mandioca e de criação de bovinos, contudo sem os devidos cuidados com o planejamento e o uso de estratégias ambientais necessários para uma produção sustentável nos assentamentos rurais familiares. Assim, sugere-se que os representantes do poder público em nível federal, estadual e local trabalhem juntos em favor da melhoria das condições do assentamento para melhorar os indicadores de sustentabilidade ambiental. A melhoria de estradas, postos de saúde e escolas no campo e da infraestrutura como um todo pode ser realizada pela prefeitura do município, por exemplo; que o INCRA, que cria 
e regulariza os assentamentos, e as instituições de assistência técnicas, como a EMATER/PA, deem condições aos produtores familiares em suas demandas produtivas de se capacitarem e desenvolverem planejamentos locais sustentáveis, como os que possibilitem minimizar os impactos ambientais de suas atividades e com isso contribuir com as organizações sociais dos assentamentos para uma maior qualidade de vida nos assentamentos rurais da região.

\section{REFERÊNCIAS}

ABRAMOVAY, R. Agricultura familiar e desenvolvimento territorial. Reforma Agrária: Revista da Associação Brasileira de Reforma Agrária, v. 28, n.1, 1999. Disponível em: http://www.econ.fea.usp.br/abramovay/artigos. Acesso: 25 maio 2016.

ALTIERI, M. Agroecologia: bases cientificas para uma agricultura sustentável. 3. ed. rev. ampl. São Paulo, Rio de Janeiro: Expressão Popular, AS-PTA 2012. Disponível em: http://www.geodados.uem.br. Acesso em: 18 jan. 2019.

BARDEN, J. E. et al. Avaliação das condições de sustentabilidade em sistemas orgânicos de produção no Vale do Taquari/RS. Cadernos de Agroecologia, v. 6, n. 2, 2011.

BAZZARELA, B. B. Caracterização e aproveitamento de água cinza para uso não potável em edificações. 2005. Dissertação (Mestrado em Engenharia Ambiental) - Universidade Federal do Espírito Santo, Vitória, 2005.

BERTUZZI, I. Produtores rurais orgânicos de Antônio Prado e Ipê, RS: analisando condições de sustentabilidade. 2012. Dissertação (Mestrado em Ambiente e Desenvolvimento) - Universidade do Vale do Taquari, Lajeado, RS. 2012.

BRASIL. Lei n. 12.727, de 17 de outubro de 2012. Brasília, DF: Presidência da República, 2012. Disponível em: http://www.planalto.gov.br/ccivil_03/_ato20112014/2012/lei/l12727.htm. Acesso em: 20 maio 2016.

BRASIL, L. S. et al. Environmental integrity and damselfly species composition in Amazonian streams at the" arc of deforestation" region, Mato Grosso, Brazil. Acta Limnologica Brasiliensia, v. 26, n. 3, p. 278-287, 2014.

BRASIL. Ministério do Desenvolvimento Agrário. Secretaria de Desenvolvimento Tecnológico. Diretrizes do Desenvolvimento Territorial. Brasília, DF: SDT-MDA, 2006. Disponível em: http://www.territórios.com.br. Acesso em: 15 fev. 2017.

BUAINAIN, A. M.; GUANZIROLI, C. M., H. Agricultura familiar: um estudo de Focalização Regional. In: CONGRESSO DA SOCIEDADE BRASILEIRA DE ECONOMIA E SOCIOLOGIA RURAL, 42., 2004, Cuiabá. Anais [...]. Cuiabá, 2004.

COSTA, M. B. B. Análise da sustentabilidade da agricultura da região metropolitana de Curitiba pela ótica da agroecologia. 2004. 281 f. Tese (Doutorado em Meio Ambiente e Desenvolvimento) - Universidade Federal do Paraná, Curitiba, 2004. 


\section{GESTÃO \& SUSTENTABILIDADE AMBIENTAL}

\section{¿unisul E}

DAROLT, M. R. As dimensões da sustentabilidade: um estudo da agricultura orgânica na região metropolitana de Curitiba-PR. 2000. Tese (Doutorado em Meio Ambiente e Desenvolvimento) - Universidade Federal do Paraná, Curitiba, 2000.

DIÁRIO DE CAMPO I: em 18/Dezembro/2015 a e b. Visita a Unidade Familiar de Produção 9 / Assentamento Canarana. Conceição do Araguaia/PA. 2014. 1-2 p.

ESPÍNDOLA, J. A. A. et al. Adubação verde: estratégia para uma agricultura sustentável. Seropédica: Embrapa Agrobiologia, 1997.

FEARNSIDE, P. Deforestation of the Brazilian Amazon. In: Oxford Research Encyclopedia, Environmental Science. Oxford: Oxford University Press, 2017. DOI: 10.1093/acrefore/9780199389414.013.102 .

FERRANTE, V. L. S. B; BARONE, L. A; DUVAL, H. C. Experiências de reforma agrária: bloqueios e perspectivas de desenvolvimento rural. Revista Lutas \& Resistências, Londrina, v. 1 , p. $76-90,2006$.

FIGUEIREDO, R. de O. et al. Effects of land use change on stream water chemistry in three meso-scale catchments in Eastern Amazonia. In: LBAECO SCIENCE TEAM MEETING, 10., 2006, Brasília, DF. Anais [...]. Brasília, DF, 2006.

GLIESSMAN, S. R. Agroecology: the ecology of sustainable food systems. 2. ed. Boca Raton: CRC Press, 2012.

HOMMA, A. K. O. et al. Os projetos de assentamentos no sudeste paraense como ciclo de ocupação. In: CONGRESSO BRASILEIRO DE ECONOMIA E SOCIOLOGIA RURAL, 40., 2002, Passo Fundo. Anais [...]. Brasília, DF: SOBER, 2002. p.3-4.

IBGE. Estatística populacional. Rio de Janeiro: IBGE, 2016. Disponível em: http://www.ibge.gov.br/home/estatistica/populacao/contagem2007/contagem_final/tabela1_1 _5.pdf. Acesso em: 28 fev. 2018.

INCRA. Instituto Nacional de Colonização e Reforma Agrária. Brasília, DF, 2015. Disponível em: http://www.incra.gov.br/. Acesso em: 02 abr. 2019.

KAUFFMAN, Boone. et al. Fire in the Brazilian Amazon 2. Biomass, nutrient pools, and losses in cattle pastures. O ecologia, v. 113, p. 415-427, 1998.

MACEDO, Cátia Oliveira. Diferenciação Socio-econômica e campesinato: 0 caso dos Assentamentos Cristo Rei, Ubá e Rio Branco no Sudeste do Pará. 198f. Tese (Doutorado em Geografia Humana) - Faculdade de Filosofia, Letras e Ciências Humanas, Universidade de São Paulo, São Paulo, 2006.

MARKEWITZ, D. et al. Nutrient loss and redistribution after forest clearing on a highly weathered soil in Amazonia. Ecological Applications, v. 14, p. S177-S199, 2004.

NEVES, J. L. Pesquisa qualitativa: características, usos e possibilidades. Caderno de Pesquisa em Administração, São Paulo, v. 1, n. 3, p.10-12. 1996.

OLIVEIRA, A. P. de. "Dinâmica Populacional e social na região Amazônica". Belém: Fundação Joaquim Nabuco, NAEA/UFPA, 1983. 


\section{GESTÃO \& SUSTENTABILIDADE AMBIENTAL}

\section{ounisul E}

ONU. Um water, statistics: graphs emaps. Drinking water, sanitation \& hygiene. New York: ONU, 2013. Disponível em: http://www.unwater.org/statustucs_san.html. Acesso em: 01 maio 2013.

PRIMAVESI, A. Manejo ecológico do solo. 18. ed. São Paulo: Nobel, 2006.

RAIJ, B. V. et al. Recomendações de adubação e calagem para o Estado de São Paulo. 2. ed. Campinas: Instituto Agronômico, 1996. (IAC. Boletim Técnico, 100).

RAZZOLINI, M. T. P.; GUNTHER, W. M. R. Impactos na saúde das deficiências de acesso à água. Rev. Saúde Sociedade, São Paulo, v. 17, n.1, p. 21-32, 2008. Disponível em: http://www.apsp.org.br/saudesociedade/index.aspx. Acesso em: 02 maio 2013.

RIBEIRO, J. W; ROOKE, J. M. S. Saneamento básico e a sua relação com o meio ambiente e a saúde pública. 2010. Monografia (Especialização em Análise Ambiental) Universidade Federal de Juiz de Fora, Juiz de Fora, 2010.

SAMPAIO, S. M. N. Dinâmica e complexidade da paisagem do projeto de assentamento Nenfica, sudeste paraense. 2008. Tese (Doutorado em Ciências Agrarias) - Universidade Federal Rural da Amazônia, Belém, 2008.

SANTOS, I. de J. P. Impactos causados pela bovinocultura de "cortes nos assentamentos de reforma agrária do Maranhão: segurança alimentar, modificação da paisagem e transformações. Lisboa: ISA/UTL, 2010.

SANTOS, M. Metamorfoses do espaço habitado. São Paulo: Hucitec. 1999.

SCHULTZ, G; BARDEN, J. E; LAROQUE, L. F. da S. Proposta metodológica para avaliação da sustentabilidade ambiental, econômica e sociocultural em propriedades rurais que atuam com sistemas orgânicos de produção agropecuária na região do Vale do Taquari, RS, Brasil. In: CONGRESSO LATINOAMERICANO Y EUROPEO EM COINNOVACIÓN DE SISTEMAS SOSTENIBLES DE SUSTENTO RURAL, 1. 2010, Lavalleja. Anais [...]. Cidade de Minas/Uruguay: INIA/Universidad de la República, 2010.

SERRÃO, E. A.S. Pastagem em área de floresta no tropico úmido brasileiro: conhecimentos atuais. In: SIMPÓSIO DO TRÓPICO ÚMIDO, 1., 1984. Belém. Anais [...]. Brasília, DF: Embrapa - SPI; Belém: Embrapa/CPATU, 1986. v. 5, p.147-174.

SILVA, L. G. T.; HOMMA, A. K. O. Política agrária e o desenvolvimento da agricultura familiar nos assentamentos do sudeste paraense. In: CONGRESSO BRASILEIRO DE ECONOMIA E SOCIOLOGIA RURAL, SOBER, 45., 2007, Londrina. Anais [...]. Londrina: SOBER, 2007. 1 CD-ROM.

SOUZA, L. da S; FIALHO, J. de F. Consorciação e rotação de culturas. Planaltina, DF: EMBRAPA, 2003.

TERENCE, M. F. Avanços e limites da reforma agrária no sul do Pará: um estudo a partir do projeto de assentamento Canarana. 2013. Dissertação (Mestrado em Geografia Humana) - Faculdade de Filosofia, Letras e Ciências Humanas, Universidade de São Paulo, São Paulo, 2013.

TOURRAND, J. F. et al. Estratégias e práticas de criação na Amazônia brasileira: dinamismo e diversidade da agricultura familiar. Montpellier: CIRAD, 1995. 


\section{GESTÃO \& SUSTENTABILIDADE AMBIENTAL \\ ¿unisul}

VEIGA, J. B; FALESI, Í. C. Recomendação e prática de adubação de pastagens cultivadas na Amazônia brasileira. In: MATTOS, Herbert Barbosa et al. Calagem e adubação de pastagens. Piracicaba: Associação Brasileira para Pesquisa de Potássio e do Fósforo, 1986. p. 256- 282.

VERONA, Luiz Augusto Ferreira. Avaliação de sustentabilidade em agroecossistemas de base familiar e em transição ecológica na região sul do Rio Grande do Sul. 2008. 192 p. Tese (Doutorado em Ciências área de concentração: Produção Vegetal) - Universidade Federal de Pelotas, Pelotas, 2008.

VIANNA, Heraldo Marelim. Pesquisa em educação: a observação. Brasília: Líber Livro, 2007.

WANDERLEY, M. de N. B. O campesinato brasileiro: uma história de resistência. Rev. Econ. Sociol. Rural, v. 52, 2014. Disponível em: https://doi.org/10.1590/S010320032014000600002. Acesso em: 22 set. 2020. 